\title{
A Strategy To Increase The International Visibility And Participation Of A State University
}

Stephen R. Lucas, (E-mail: srlucas@uncg.edu), University of North Carolina, Greensboro Benton E. Miles, (E-mail: bemiles@ uncg.edu), University of North Carolina, Greensboro

\begin{abstract}
This paper presents a strategy for expanding a university's international participation. An effort to correct international exchange imbalances evolved into a unique international program and partnership with Walt Disney World.
\end{abstract}

\section{INTRODUCTION}

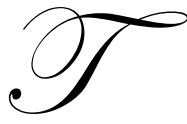

he UNCG-Bryan School/Walt Disney World College Program (UNCG/Disney) for international exchange students is currently in its sixth year of operation. For the first five years, this program exclusively served the exchange student population from the Tec de Monterrey. Beginning in January 2006, the program was expanded to include students from Macquarie University, one of UNCG's Australian partner schools. Currently, there are students from schools in six countries that are participating in the program: Australia, Canada, Ireland, Mexico, and Switzerland.

What started as an effort to correct an imbalance in the ratio of UNCG (U.S) students wanting to study in Mexico and the Mexican students wanting to study at UNCG has evolved into a unique international program which includes a partnership with Walt Disney World.

\section{PROGRAM OBJECTIVES}

There are seven key objectives for the Bryan School:

1. Increase the visibility of UNCG internationally by establishing relationships with universities throughout the world.

2. Increase the number of exchange positions at selected international universities where UNCG had more students wanting to go to the international school than there were students at that school wanting to come to UNCG.

3. Enable students at universities that are not viable exchange partners, because of various reasons (such as lack of available courses taught in English and curricula not compatible with UNCG), to participate in a direct-to-Disney arrangement with UNCG sponsorship.

4. Increase the number of international students on the UNCG campus so that the UNCG students, on campus, will have a more enriched experience.

5. $\quad$ Produce adequate funding to operate the program (dollars as well as student credit hours).

6. Increase the number of visiting international faculty to aid in internationalizing the campus.

7. Generate adequate student credit hours $(\mathrm{SCH})$ per semester to justify the faculty line.

These objectives will be met by operating the Bryan School Disney Program as a custom-designed program that can function on a reciprocal basis as well as a fee-based basis. By adapting the program design to meet needs on a case-by-case basis, the program can generate $\mathrm{SCH}$, increase reciprocal exchange spots, and operate as a selfsupporting unit. 


\section{PROGRAM PARTICIPATION OPTIONS}

There are several ways for the international student to participate in the UNCG/WDW program; the following are examples of the methods of participation. These methods can be modified to meet the needs of UNCG as well as the international school.

1. Attend UNCG for one semester as a full-time student on an exchange basis and, in the second semester, the international student will participate in the WDW College Program at Walt Disney World on a fee-paid basis.

2. Attend UNCG for one semester as a full-time student on an exchange basis and, in the second semester, the international student will participate in the WDW College Program at Walt Disney World on an exchange basis.

3. The international student will go directly to Disney to participate in the WDW College Program at Walt Disney World on a fee-paid basis.

4. The international student will go directly to Disney to participate in the WDW College Program at Walt Disney World on a combination of exchange and fee-paid basis.

Disney has four educational and participation periods: 1. The Spring (Jan. to May), 2. The Spring Advantage (Jan. to Aug.), 3 The Fall Advantage (May to Jan.), and 4. The Fall (Aug. to Jan.). With a few exceptions, Disney has insisted that the international students participate in an Advantage Program. All of the Monterrey Tec students have participated in an Advantage Program. It is extremely difficult, although not impossible, for a student to complete the academic work required for twelve hours of classes and work the hours Disney's desires during either the Spring (1) or Fall (4) Program. The coordinator of the program must be available to evaluate assignments, assist students with problems (both academic and Disney-related) throughout the calendar year. There are more students participating in the UNCG-Disney program during the summer than at any other time. It is important to note that this program is a 12-month program. In order to meet the terms of the J-1 student visa, the participants must maintain full-time student status, year-round. Students will be engaged in educational activities during the entire time that they are in Orlando as well as during any time that they are on the UNCG campus.

\section{UNCG'S COMPETITIVE ADVANTAGES - WHY UNCG?}

1. The Bryan School of Business and Economics is internationally accredited by the AACSB, International. The AACSB, International accreditation is respected throughout the world. Several international universities have selected to participate with UNCG, in part, because of the Bryan School's accreditation.

2. The international students, enrolled at UNCG and participating in the WDW College Program, will have close contact with the Bryan School faculty while at Disney. Bryan School faculty members visit the students at Disney several times each semester. The students have weekly or bi-weekly contact with Bryan School faculty. A Bryan School faculty member is on the Board of the Walt Disney College Program; this membership builds a close relationship between UNCG and WDW College Program and, therefore, allows for participation in resolving student issues.

3. The Bryan School has had a successful, international program with WDW for more than five years. Disney's international college exchange program was created by an arrangement among the Tec de Monterrey University, the Bryan School, and the WDW College Program. The success of the original program provided encouragement to Disney College Program officials to make the international exchange program available to other U.S. and international colleges/universities.

4. UNCG has designed twelve hours of courses to be used, primarily, by international students participating in the Walt Disney World College Program. Disney lends itself to being a "learning laboratory" for the application of theory taught in the university classroom. For instance, each month a calendar of potential learning activities is made available to all Disney College Program students. The activities range from an interview with a Disney vice-president to a planned, Disney charity event in the community. 


\section{IDENTIFICATION OF CHALLENGES IN ADMINISTERING THE PROGRAM AND POSSIBLE SOLUTIONS}

1. Time-consuming - Managing the Bryan School/Disney Program is time-consuming. Therefore, the program coordinator must be available to respond to assignment questions and student needs. The responsibilities for this program do not stop for holidays and summer periods. Additionally, recruitment for the program, internationally, takes place throughout the calendar year.

2. Costly - The Bryan School/Disney Program Coordinator needs to be employed on a twelve-month basis. This arrangement is beyond the normal employment arrangement for a faculty member. In addition, the twelve-month employee needs an administrative assistant. The administrative assistant will perform a variety of tasks such as organizing the Disney meetings on campus, accessing and printing e-mail student reports/messages, arranging the Coordinator's travel, and corresponding with Disney College Program Office personnel regarding Disney housing and educational matters.

3. International travel - It is necessary to travel with (and without) Disney representatives to explain the educational component of the Bryan School/Disney Program. During these visits the faculty member will meet with students, faculty, and administrators at the international universities.

4. Travel to WDW - It is imperative that a U.S. university representative (in this case, a member of the Bryan School faculty) meets the international student participants upon their arrival at Disney. During this meeting, questions are answered and the educational component is explained. The major effort is to make them feel a part of UNCG, even though the students may be going direct-to-Disney (UNCG t-shirts were appreciated by the students). Another important item to be accomplished is to process all student visa material.

\section{FUTURE OPPORTUNITIES FOR EXPANSION}

Disney is currently in an expansion mode and has indicated that there is no reasonable limit on the numbers of international students that we can send to participate in this program. There is a plan in place whereby representatives of the UNCG International Programs Center present the Disney program option to UNCG's current exchange partners in an effort to increase exchange opportunities for UNCG students. In addition, they are in the process of discussing possible arrangements for the UNCG-Bryan School/Disney Program with potentially new partner schools in areas of the world where, currently, we do not have opportunities.

Looking to the future, the coordinator of the program in the Bryan School and personnel in the UNCG International Program Center anticipate that the number of students will increase each semester. The increase in the number of students as well as the number of universities participating in the program will enhance UNCG's visibility in the international community and open up opportunities for UNCG students to engage in study abroad programs. 


\section{NOTES}

